Удк 616.366-002-036.11-06:616.367]-003.7-072.1-073.8:681.3]-035

DOI 10.11603/2414-4533.2016.4.7183

() С. І. САВОЛЮК, Б. В. СВИРИДЮК

Національна медична академія післядипломної освіти імені П. Л. Шупика

Київська міська клінічна лікарня № 8

\title{
Діагностичний алгоритм у хворих із гострим калькульозним холециститом та підозрою на холедохолітіаз
}

\author{
S. I. SAVOLIUK, B. V. SVYRYDIUK \\ P. Shupyk National Medical Academy of Postgraduate Education \\ Kyiv City Clinical Hospital № 8
}

\section{DIAGNOSTIC ALGORITHM FOR PATIENTS WITH AN ACUTE CALCULARY CHOLECYSTITIS AND SUSPICION ON CHOLEDOCHOLITHIASIS}

\begin{abstract}
Проведено аналіз інструментальної діагностики 316 хворих на гострий калькульозний холецистит із підозрою на холедохолітіаз. У даній групі хворих чоловіків було 105 (33,2 \%), жінок - 211 (66,8 \%). Вік хворих - від 42 до 84 років. Всі пацієнти були обстежені відповідно до протоколів та стандартів надання медичної допомоги клініко-лабораторно, інструментально.

У день госпіталізації хворим виконано УЗД ОЧП з подальшим УЗ-контролем наступного дня після відповідної підготовки. Під час УЗД ОЧП діагностовано 97 випадків холедохолітіазу, що дозволило відразу планувати операційне втручання. Всіх інших хворих поділено на дві групи. У першій групі (115 хворих) для подальшої діагностики виконували ЕРПХГ, в другій групі (104 хворих) - МР ПХГ. За результатами досліджень, встановлено, що МР ПХГ має чутливість у діагностиці холедохолітіазу 99 \%, а ЕРПХГ - 97,1 \%.

Важливо відмітити, що виконання ЕРПХГ може супроводжуватись такими ускладненнями, як алергічні реакції, гострий холангіт та гострий холецистит, які ми спостерігали у 5 випадках $(4,3 \%)$. При виконанні МР ПХГ ускладнень не відзначили. Іншою перевагою МР ПХГ є забезпечення 3D-візуалізації протокової системи, що полегшує оперування, сприяє зменшенню часу операції та кількості операційних ускладнень, у тому числі ятрогенних.
\end{abstract}

\begin{abstract}
An analysis of instrumental diagnostic of 316 patients with acute calculous cholecystitis and suspicion of choledoholitiasis was conducted. In that group of patients there were 105 (33.2 \%) men and 211 (66.8 \%) women aged from 42 to 84 years. All patients were examined in accordance to protocols and standarts of providing medical help (include clinical, instrumental and laboratory parameters). At the day of hospitalization all patients underwent examination by ultrasonic diagnostic of abdominal organs with ultrasonic control next day after appropriate preparation.

Due to ultrasonic diagnostic of abdominal organs we found 97 cases of choledoholitiasis which allowed us to prepare patients to surgical operation.

All other patients were divided in two groups. In the first group (115 patients) to continue diagnostic retrograde pancreatoholangiography was practised. In the second one (104 patients) there was used MR pancreatoholangiography. As a result of diagnostic it was found that MR pancreatoholangiography has sensitivity to reveal choledoholitiasis in $99 \%$ of cases instead of $97.1 \%$ by retrograde pancreatoholangiography.

Importantly that carrying out of retrograde pancreatoholangiography could accompanied with allergic reactions, acute cholangitis and acute cholecystitis(we had 5 such cases (4.3\%)). At carrying out MR pancreatoholangiography complications were not observed. Other benefit of MR pancreatoholangiography is 3D visualization of duct system, what simplify surgical operation, reducing the time of operation and complications after surgery (include iatrogenic).
\end{abstract}

Постановка проблеми і аналіз останніх досліджень та публікацій. На сьогодні гострий холецистит є одним із найпоширеніших гострих хірургічних захворювань, становить близько 1520 \% від всіх гострих хірургічних захворювань черевної порожнини і поступається лише гострому апендициту, а, за даними деяких авторів, це найбільш часта ургентна абдомінальна патологія.

Незважаючи на зростання частоти захворювань на жовчнокам'яну хворобу, яка ускладнена холедохолітіазом, диференційна діагностика цієї патології $є$ тяжкою, що зумовлено складністю анатомо-фізіологічних відносин органів гепатопанкреатобіліарної зони [1, 2].

Основними інструментальними методами діагностики причин непрохідності жовчних проток непухлинного походження $є$ ультразвукове дослідження (УЗД), комп'ютерна томографія, ендоскопічна ретроградна панкреатохолангіографія (ЕРПХГ), діагностична ендоскопічна папілотомія 


\section{З ДОСВІДУ РОБОТИ}

(ЕПСТ), магнітно-резонансна томографія (МРТ) та магнітно-резонансна панкреатохолангіографія (МР ПХГ), трансдуоденальна холедохоскопія, фістулохолангіографія.

Найбільш розповсюдженим та доступним методом діагностики гострого холециститу з холедохолітіазом є УЗД ОЧП. Ефективність цього методу, за даними різних авторів, складає від 40-50 до 84-98 \% [3].

Виділяють прямі та непрямі ехографічні ознаки холедохолітіазу. До прямих ознак відносять наявність у просвіті загальної жовчної протоки ехогенного утвору з акустичною тінню. До непрямих ознак відносять розширення гепатикохоледоха, внутрішньопечінкових проток, ехогенні структури без чіткої акустичної тіні в просвіті, розширення вірсунгової протоки.

E. H. Phillips et al. (1993) відмічає, що при поєднанні чотирьох факторів - холангіт, розширення загальної жовчної протоки більш ніж 8 мм, збільшення вмісту трансаміназ та білірубіну - вірогідність холедохолітіазу сягає 99 \%, при відсутності цих факторів - 7\%.

Наприкінці минулого століття найпоширенішим та найефективнішим методом передопераційної діагностики холедохолітіазу була ЕРПХГ, актуальність цього методу в діагностиці захворювань органів гепатопанкреатобіліарної зони зберігається до цього часу [4]. Для контрастування жовчних проток використовують водорозчинні препарати: тріомбраст, урографін, уротраст, верографін. Введення контрастної речовини може супроводжуватися вираженим больовим синдромом та в подальшому призводити до розвитку алергічних реакцій, холангіту, гострого панкреатиту. Щодо діагностики холедохолітіазу, на думку деяких авторів, методика значно поступається МР ПХГ. Так, за даними вчених, чутливість та специфічність цього методу дорівнює 100 \% [5].

МР ПХГ є безпечним методом дослідження завдяки неінвазивності та відсутності необхідності введення контрастних речовин. Проведення цього дослідження дозволяє в багатьох діагностичних ситуаціях замінити прямі методи контрастування - ендоскопічну ретроградну холангіопанкреатографію, а також черезшкірну черезпечінкову холангіографію. МР ПХГ може бути методом діагностичного вибору у хворих, які потребують неінвазивної холангіографії, а також при складній анатомії жовчних шляхів та при протипоказаннях до проведення рентгенендоскопічних досліджень (декомпенсований стан хворого, несприйняття контрастних препаратів та ін.) чи неможливості їх виконання.
Поряд 3 аналізом тонких зрізів можлива 3D-реконструкція з використанням MIP-алгоритму, що забезпечує найбільш чітку просторову картину протокової системи та дозволяє точно визначити рівень обструкції біліарного дерева чи протоки підшлункової залози, покращує візуалізацію структур і дозволяє планувати хірургічні та ендоскопічні маніпуляції. В процесі підготовки до холецистектомії особливу увагу звертали на довжину, діаметр та форму міхурової протоки, особливості їі впадання в загальну жовчну протоку, на варіанти будови і злиття печінкових проток. Ще однією перевагою МР ПХГ є відсутність променевого навантаження у пацієнта та медичного персоналу [6].

Мета роботи: порівняти результати діагностики холедохолітіазу у хворих на гострий калькульозний холецистит за допомогою ЕРПХГ та МР ПХГ з метою напрацювання оптимального діагностичного алгоритму.

Матеріали і методи. У дослідження включено 316 пацієнтів віком від 42 до 87 років з гострим калькульозним холециститом та підозрою на холедохолітіаз, що перебували на лікуванні та оперовані в хірургічних відділеннях КМКЛ № 8. Жінок в дослідженні було 211 (66,8 \%), чоловіків - 105 (33,2 \%). Середній вік хворих становив $(62,6 \pm 2,4)$ року.

Відповідно до протоколів та стандартів надання медичної допомоги хірургічним хворим із гострим холециститом, який ускладнений холедохолітіазом, крім клініко-лабораторного обстеження, виконували ряд інструментальних методів дослідження. При проведенні обстеження ми дотримувалися такого принципу: від менш інвазивного та технічно простого методу дослідження - до більш інвазивного та технічно складного.

Згідно з протоколом дослідження, пацієнтам проводили загальний і біохімічний аналізи крові й загальний аналіз сечі, визначали стан системи згортання крові та групу крові з резус-фактором. Для аналізу крові використовували автоматичні і напівавтоматичні гематологічні, біохімічні та імуноферментні аналізатори.

Всім хворим виконували ЕКГ, рентгенологічне дослідження органів черевної та, при потребі, грудної порожнини.

Проводили ультразвукове дослідження органів черевної порожнини. Хоча цей метод не має високої чутливості, але в ряді випадків дозволяє виявити конкременти і не виконувати зайвих досліджень, тобто завершити діагностичний пошук та розпочати планування операційного лікування. 
Перед виконанням ЕРПХГ проводили гастродуоденоскопію, що дозволяє здійснити детальну ревізію не тільки шлунка, дванадцятипалої кишки, але і ВС ДПК - визначити його форму, величину, стан слизової оболонки, наявність патологічних утворів - поліпів, пухлини, дивертикулів, стриктур.

Показаннями до виконання ЕРПХГ вважали наявність ЖКХ в анамнезі, клініки холангіту, дилатацію гепатикохоледоха за даними УЗД ОЧП більше 8 мм, характерні зміни в біохімічному аналізі крові - гіпербілірубінемію більше за рахунок прямої фракції, підвищення рівня показників холестазу (ЛФ) та цитолізу (АлАТ, АсАТ), тобто наявність клініко-лабораторних даних підвищеної ймовірності холедохолітіазу, який не діагностовано за допомогою УЗД.

Основні показання до проведення МР ПХГ хворим з підозрою на ЖКХ були багато в чому подібні: часті епізоди больового синдрому в правому підребер’ї, епізоди ремітуючої жовтяниці, розширення жовчних проток за даними УЗД, необхідність уточнення наявності та кількості конкрементів у жовчному міхурі, їх якісна оцінка (розташування і хімічний склад), вивчення особливостей будови жовчовивідних шляхів при підготовці до холецистектомії.

Результати досліджень та їх обговорення. Всі хворі були обстежені клініко-лабораторно, інструментально відповідно до стандартів надання медичної допомоги хірургічним хворим із гострим холециститом. Особливу увагу на першому етапі лікувально-діагностичного пошуку приділяли результатам УЗД ОЧП. Враховуючи тяжкість візуалізації позапечінкових жовчних проток, як правило, дослідження повторювали наступної після госпіталізації доби, після відповідної підготовки хворого.

У випадку наявності клінічних симптомів, отримання прямих ознак холедохолітіазу на УЗД ОЧП та характерних змін в біохімічному аналізі крові діагностичний пошук припиняли та починали планувати операційне втручання. В нашому дослідженні за допомогою УЗ-дослідження вдалось діагностувати гострий калькульозний холецистит та холедохолітіаз у 97 випадках, що знайшло своє підтвердження інтраопераційно у 94 хворих. Характерно, що у значної більшості пацієнтів - 74 (76,3 \%) відмічали розширення загальної жовчної та внутрішньопечінкових жовчних проток, розмір конкремента у 62 (63,9 \%) випадках перевищував 10 мм.

У випадку відсутності прямих УЗ-ознак холедохолітіазу або відсутності кореляції результатів
УЗД ОЧП з клініко-лабораторними показниками виконували інші інструментальні дослідження. В першій групі хворих виконували ЕРПХГ, в другій групі хворих - МР ПХГ.

ЕРПХГ виконано 115 пацієнтам, що дозволило діагностувати конкременти у 107 хворих, інтраопераційно підтверджено діагноз у 101 (94,4%) хворого. У трьох випадках отримано хибнонегативний результат, в результаті чого у 2 пацієнтів після виконання лапароскопічної холецистектомії відмічались атаки холангіту, в одному випадку з розвитком механічної жовтяниці - виконано повторну ЕРПХГ з ЕПСТ, що привело до одужання хворих. У ще одному випадку діагноз холедохолітіазу встановлено інтраопераційно - виконано холедохолітотомію. Таким чином, чутливість методу склала 97,1 \%.

У одному випадку спостерігали алергічну реакцію на введення контрастної рідини у вигляді нудоти, шкірного свербежу, головокружіння. У двох хворих після проведення дослідження спостерігали атаки гострого холангіту з гіпертермією до 39-40 ㄷ та вираженим больовим синдромом. У двох випадках після контрастування жовчного міхура мав місце розвиток деструктивного холециститу, що потребувало операційного лікування за екстреними показаннями.

У нашому дослідженні МР ПХГ виконано 104 хворим II групи, що дозволило діагностувати холедохолітіаз у 98 випадках та знайшло підтвердження під час виконання операційних втручань у 100 \% хворих. Побічних ефектів, ускладнень методу не спостерігали. В 1 хворого післяопераційний період ускладнився розвитком механічної жовтяниці, з приводу чого виконано ЕРПХГ, діагностовано мікрохоледохолітіаз та обмежений папілостеноз. Виконано ЕПСТ, хворого виписано в задовільному стані. Чутливість методу склала 99,0 \%.

Іншою перевагою МР ПХГ є чітке розуміння співвідношення структур у ділянці операції, що значно спрощує оперування та запобігає розвитку післяопераційних ускладнень, в тому числі і ятрогеній. Крім того, слід відзначити відсутність променевого навантаження хворого та медперсоналу.

У хворих із гострим калькульозним холециститом в поєднанні з холедохолітіазом застосовували одно- або двохетапну тактику хірургічного лікування. Всіх хворих прооперовано за допомогою малоінвазивних методик. Холецистектомію та холедохолітотомію проводили з міні-доступу в правому підребер’ї або лапароскопічно. У разі використання двохетапної тактики один із етапів (папілотомію) виконували ендоскопічно. При порівнянні середнього часу операції відміча- 


\section{З ДОСВІДУ РОБОТИ}

ли зменшення часу в II групі за рахунок чіткого розуміння хірургічної анатомії та більш впевненого оперування - $(128,3 \pm 25,3)$ та $(120,4+21,5)$ хв при виконанні одноетапних втручань, $(49,8 \pm 11,4)$ та $(43,5+9,4)$ хв при виконанні холецистектомії при двохетапних операційних втручаннях.

У І групі виконано 2 конверсії: одну за розсудом у випадку неможливості диференціювання елементів трикутника Кало, іншу за вимогою - у випадку крайового пошкодження загальної жовчної протоки, у II групі виконано 1 конверсію за розсудом через наявність щільного інфільтрату в ділянці гепатодуоденальної зв’язки.

Висновки. 1. МР ПХГ є сучасним методом виявлення холедохолітіазу і не залежить від форми холециститу, діаметрів ЗЖП та конкремен-

\section{СПИСОК ЛІТЕРАТУРИ}

1. Алгоритм диференційної і топічної діагностики обтураційної жовтяниці та міні-інвазивної корекції прохідності магістральних жовчовивідних шляхів / М. Ю. Ничитайло, П. В. Огородник, А. Г. Дейниченко [та ін.] // Клінічна хірургія. - 2012. - № 2. - С. 5-10.

2. Дооперационная диагностика скрытого холедохолитиаза / Т. Б. Ардасенов, Д. А. Фрейдович, А. Г. Паньков [и др.] // Анналы хирургической гепатологии. - 2011. - № 2. - С. 15-19. 3. Accuracy of ultrasonography in the diagnosis of acute calculous cholecystitis: review of the literature / A. Pinto, A. Reginelli, L. Cagini [et al.] // Crit Ultrasound J. - 2013. - № 5. - P. 11. та, що не має ускладнень. Чутливість МР ПХГ у діагностиці холедохолітіазу сягає 99 \%, тоді як ЕРПХГ- 97,1 \%.

2. Показаннями до ЕРПХГ, за нашим алгоритмом діагностики, є випадки, коли після виявлення холедохолітіазу слідує виконання ЕПСТ. Запропонований діагностичний алгоритм сприяє успішній доопераційній діагностиці холедохолітіазу, виконанню найбільш оптимального та обгрунтованого лапароскопічного, ендоскопічного або іншого операційного втручання, зменшує час операційного втручання за рахунок чіткого уявлення про варіант хірургічної анатомії в кожного конкретного хворого, а також запобігає повторним хірургічним втручанням на жовчних шляхах 3 приводу резидуального холедохолітіазу та можливим ятрогенним пошкодженням.

4. Бойко В. В. Холедохолитиаз, диагностика и оперативное лечение / В. В. Бойко, Г. А. Клименко, А. В. Малоштан // Хирургия : Новое слово, 2008. - 216 с.

5. Емельянов С. И. Роль магнитно-резонансной томографии при желчнокаменной болезни, ее осложнениях и в диагностическом сопровождении больных после оперативного лечения холелитиаза / С. И. Емельянов, А. М. Петров // Эндоскопическая хирургия. - 2011. - № 6. - С. 21-23.

6. Diagnosis of acute cholecystitis: value of contrast agent in the gallbladder and cystic duct on Gd-EOB-DTPA enhanced MR cholangiography / I. Y. Choi, S. H. Cha, S. K. Yeom [et al.] // Clin. Imaging. - 2013. - № 13. - P. 00234-00239.

Отримано 10.05.16 